\title{
Identity problems: an interview with John B. Davis
}

JOHN B. DAVIS is professor of economics at Marquette University (USA) and professor of the history and philosophy of economics at the University of Amsterdam (Netherlands). He holds PhDs in both philosophy (1983, University of Illinois; under the supervision of Richard Schacht) and economics (1985, Michigan State University; under the supervision of John P. Henderson and Warren J. Samuels).

He has published on many areas in the philosophy, history, ethics, and methodology of economics. His published monographs include Keynes's philosophical development (Cambridge, 1994); The theory of the individual in economics (Routledge, 2003); and Individuals and identity in economics (Cambridge, 2011). He co-authored Economic methodology: understanding economics as a science (Palgrave, 2010) with Marcel Boumans. In addition to his research on identity and the theory of the individual, he has written extensively on recent changes in economics. He is a past president of the History of Economics Society (HES), the International Network for Economic Method (INEM), and the Association for Social Economics (ASE), and past vice-president of the European Society for the History of Economic Thought (ESHET). He is a past editor of the Review of Social Economy, and is currently co-editor with D. Wade Hands of the Journal of Economic Methodology.

In this interview, Professor Davis discusses the evolution of his career and research interests as a philosopher-economist and gives his perspective on a number of important issues in the field. He argues that historians and methodologists of economics should be engaged in the practice of economics, and that historians should be more open to philosophical analysis of the content of economic ideas. He suggests that the history of recent economics is a particularly fruitful and important area for research exactly because it is an open-ended story that is very relevant to understanding the underlying concerns and concepts of contemporary economics. He discusses his engagement with heterodox economics schools, and their engagement with a rapidly changing mainstream economics. He argues that the theory of the

EJPE's NoTE: This interview was conducted by Thomas Wells, co-editor of the Erasmus Journal for Philosophy and Economics. 
individual is "the central philosophical issue in economics" and discusses his extensive contributions to the issue.

\section{EJPE: Professor Davis, you are unusual in having PhDs in both philosophy and economics. Is there a story behind that? How do you manage your identities as philosopher and economist?}

JONH DAVIS: Like many people, much of the story of how I happened to do what I have done was the result of the chances of life. I began in philosophy at the University of Illinois after dismissing my adolescent assumption that I would be a lawyer, but found as I moved to complete the degree that the job market was very poor and that my prospects for teaching philosophy anywhere were not good. At the same time, though I came from a suburban Chicago solidly middle class Republican background, I was radicalized in the 1970s by the Vietnam War, and decided that philosophy was too ivory tower and that economics (whatever that was) mattered. So before I finished my philosophy thesis I started at the University of Michigan in economics. But my first micro course with Hal Varian, where solving problems was more important than interpreting them, quickly demonstrated to me that I had to get my comparative advantage straight. That turned out to be the connection between the history of philosophy (one of my fields at Illinois; ethics was the other) and the history of economics.

Up the road was Michigan State University, where they then had four historians of economics and multiple courses in the field. Moving there, I was able to finish both degrees, finishing my philosophy dissertation while I was studying for my economics prelims. Youth has its advantages! That I was able to do both degrees, I think, was in good part due to the low cost of living and teaching assistant income then for graduate students at public universities (though mentors were also very important). One could survive, and even raise a family, while studying most of the time. That world, unfortunately, is now long gone, at least in the United States, where most people must indenture themselves to lenders to pursue advanced study.

I have managed my two identities by following a particular career pathway. I do not specialize or publish in the professional philosophy literature but concentrate on the history and methodology of economics literature. Partly this has been strategic: it is difficult to write and be successful in publishing if one has to communicate with two rather disparate audiences at the same time, and even philosophers of 
economics tend to look at issues quite differently from methodologists of economics. Partly it has been because I thought economics more important for what happens in the world. Still, this choice placed me in two small subfields in economics (history and methodology) which also do not communicate very well. Nonetheless, I have always thought the philosophical or methodological dimensions of the history of economics a fertile intellectual domain (as have others in the history of economics: Smith, Marx, Keynes, and Sen, for example). Whether this kind of strategy is workable in the future is hard to say. Without the current system of secure long-term employment in academia, which may be endangered, the forces for 'homogenizing' research that discourage interdisciplinary niche research may be too strong.

Also on the subject of identities, I have taught in economics my whole career. This has meant I have learned to think like an economist, where one moves step by step in a fairly linear way, which is quite different from thinking like a philosopher, where rival foundational assumptions are always being juggled and traded-off against one another so that the whole explanatory picture can transmutate before one's eyes with a small change in assumptions.

I like both types of thinking, but there is something to be said for focusing on the explanatory task economists see themselves addressing for grasping the logic of economic thinking. Some philosophers and methodologists of economics, in my view, fail in this regard. They come forward with good philosophical arguments, but they do not quite get at what the issues are for economists. So I was opposed to the idea, floated a number of years ago in the history of thought community-and the subject of a 1992 History of Political Economy symposium responding to the 'breaking away' proposal of Margaret Schabas (1992)-that historians of economics ought to migrate away from economics to find homes in history and philosophy of science programs. Teaching economics and having economics colleagues is in my view important for properly understanding the philosophical and methodological issues in economics.

I think you are also unusual in the range of areas you have published on, from the history and philosophy of economics to recent history of economics to heterodox economics (especially social economics) to identity. How do these link together, if they do? How have your 


\section{interests evolved? Would you recommend this approach to anyone else?}

I think there are more people than one might think who maintain multiple research programs, even in quite different subjects. Often there are links that one discovers in a natural way as one just happens on connections between things. But researchers can also have different interests without quite knowing how they connect. Or the connection is a somewhat path-dependent product of one's history of interaction with other researchers (often at conferences, outside of sessions), whose work strikes one as interesting, and who suggest ideas and ask critical questions.

Broadly speaking, the reason for my attachment to heterodox economics-aside from my politics-goes back to my philosophy training. Philosophy, with its attention to conceptual depth and the multiple interconnections between ideas, naturally invites one to ask whether tightly defined behavioral relationships, as in utility maximization analysis and competitive market theory, are not dependent on a host of underlying assumptions and ideas regarding institutions, norms, social values, and so on, that lie behind these behavioral relationships. So one (methodological) definition of heterodox economics-one not used by many it seems-is that it is an approach that insists on going beyond surface explanations to more holistic, in-depth explanations.

Mainstream economics says this is unnecessary on the grounds that the more immediate analysis/model sufficiently communicates causeand-effect relationships. Heterodox economists reject that, and indeed argue that a tight logic can be wrong or misunderstood absent an appreciation of what the analysis/model more deeply presupposes. This makes the difference between mainstream and heterodox economics less a matter of content and politics and more a matter of different philosophies of science. I think the recent financial crisis demonstrates that the heterodox approach to science in terms of conceptual depth is better. But the surface model of science that dominates the mainstream is well-entrenched (perhaps reflective of the strong influence of American culture on science). This all ties in also to the mathematization of economics and the expulsion of narrative from scientific explanation, as associated with the recent decline of history of economics and economic history in economics departments. 
My long involvement with social economics (particularly in eighteen years of editing the Review of Social Economy)-which led me to work on the individual and identity-derives from a combination of philosophical curiosity and a preference for a heterodox economics that emphasizes social values. My training in ethics and philosophy of science made it clear to me from early on that science is always valueladen. When you see the world both in-depth and as pervaded by value you find you need to think of individuals as social and not atomistic. This all led me to what I saw as the central dilemma in the theory of the individual-how a person can be social and individual at the same time-which I tried to work out for myself by formulating two identity conditions for what individuals are which enable us to formulate social and relational conceptions of individuals.

There was another important influence on my thinking about the individual in economics. When I first began working on the individual I could not get over the ideological character of the Homo economicus conception, i.e., that it was not just a benign tool of economic analysis but figured centrally in liberal society's vision of itself and economics' one-sided promotion of that vision. One of the things I learned from Warren Samuels was that economists commonly put themselves in service to 'mythic devices', as he put it. Thus for him an important task of methodological analysis in economics was to ferret out these attachments and expose them to fair analysis. In his late life work he performed a similar kind of analysis of the invisible hand, arguing in his Erasing the invisible hand (2011) that this idea central to economics is a largely ideological one that functions as a 'psychic balm' and means of social control. So I think Warren disposed me to looking critically beneath the so-called 'scientific' surface of economic ideas to the silent work they often perform. Indeed, the invisible hand and Homo economicus seem to occupy coordinate roles in this regard.

Regarding moving back and forth across multiple personal research programs, I recommend this for a number of reasons. There is the practical matter of diversifying one's credentials. I think it is also intellectually more satisfying, particularly over a long work life, to investigate many things. One should be open to where research takes you, since unanticipated subjects of investigation often drive one to develop new ideas, and one does not want to foreclose these possibilities at the cost of one's research becoming repetitive and tedious. I was thus fortunate to teach for ten years at the University 
of Amsterdam, since this gave me the opportunity to do something new, namely investigate new research programs in economics from an historical perspective-something which cannot be separated, I should add, from being able to work with the interesting and talented colleagues I had there.

\section{Moving to particular themes from your work. How would you describe your approach to the history of economic thought?}

The Amsterdam group in the History and Methodology of Economics (HME) - which was closed in early 2011 (more on this below)-argued that the history and methodology of economics are inseparable, a view not shared by that many historians and methodologists of economics, who tend to be fully specialized in one or the other field. Indeed some in the history of economics community do not hesitate to say that methodology/philosophy of economics type arguments have no place in history of economics journals, and for this reason submissions to history of economics journals that identify philosophical arguments in the history of economics are sometimes rejected without serious review.

Why do many historians hold this separability view? I think the answer is connected to a change in recent years in the way the history of economics is done (something I think shows up when you compare contemporary historians with the generation who founded the History of Political Economy). The history of economics used to be practiced as the history of economic thought, where this was seen as the study of theory, ideas, and economic doctrine. In the reaction against this approach (beginning perhaps in the 1990s), historians of economics increasingly argued that their job was not to explicate and evaluate different doctrinal positions, but that it was their job to describe how economic views were developed by their proponents. Contributing to this view at the time were two developments: (1) History of Economics Society conferences in the 1980s and 1990s were often the site of contests between rival heterodox economists, and (2) many methodologists of economics adopted sociology of scientific knowledge views which described how economists/scientists behaved and happened to come about their views rather than what the rational content of those views might be. The first development generated professional concern that the history of economics was not a legitimate subfield-at a time when the economics profession was already skeptical about its value-while 
the second development provided a model of scholarship which was neutral regarding the status of economic doctrine (if not also positivistic).

The outcome of this was that by the end of the millennium historians had made archival work foundational to the practice of the field-something that was rarely done previously. 'New' evidence was not surprisingly a fairly solid route to publication (in a time when pressure to publish was being extended to historians of economics), and perhaps more respectable in the eyes of economists generally. And perhaps there were also diminishing returns by then in a fairly mature history of economics community to further doctrinal analysis. In any event, at least in my view, a kind of historiographic positivism became characteristic of much work in the history of economics, and this made-as a not entirely unintended consequence-methodological/ philosophical reasoning regarding the history of economics relatively unwelcome in the field.

Of course it would be wrong to say that archival work (which I have done as well) is not valuable, just as it would be wrong to say that published materials are never sufficient for understanding the ideas in question. The immediate issue is rather the practice of excluding philosophical and methodological reasoning from the history of economics; the longer term issue is whether history of economics becomes impoverished when it avoids philosophical argument.

I will not enter here into the general arguments in favor of the view (defended at Amsterdam) that history and methodology/philosophy of economics are inseparable-though I think they are compelling once one looks at the issue-but rather comment on why I personally hold this view. It comes from my being trained in philosophy prior to being trained in economics. Essentially I believe philosophical positions underlie all positions in economic theory and practice, and the view that the former (if acknowledged) can be bracketed off from the latter seems to me mistaken. This is not to say that one cannot focus on economics and its history without raising methodological and philosophical issues. Of course one can. Rather, one just does not get down to the key foundations for the views people have when one stops short of the deep conceptual commitments they assume (knowingly or not). So if many people prefer to stop short in this way, this seems to me to be a nice argument for having some people specialized in methodology and 
philosophy of economics, as we have now. The latter just should not be excluded from the history journals.

At Amsterdam, the HME group also emphasized (though not exclusively) the history of recent economics, namely the second half of the sixty year postwar period when, after 1980, new research programs began to appear in the field. We saw this as an important extension of the history of economics, both in time coverage and historiographically speaking. Regarding the latter point, an important difference about the recent history of economics is that the story remains significantly open, unlike the earlier history of economics, where historical episodes are largely complete in the sense that old ideas have been replaced by new ones in current practice. We used this difference at Amsterdam to argue that one needs economic methodology to understand unfinished histories, because it provides grounds for assessing the merits of research programs. This, it should be added, is a different historiographic procedure than usually employed with completed (albeit interpretively open) histories of economics, because there we tend to put aside their epistemic and ontological credentials, simply charting why some programs prospered and others did not. The fact that history goes one way or another is important, but the window that methodology/philosophy opens on history has its own analytical advantages that historians risk not appreciating.

A corollary of this view is that practitioner economists in the current contested terrain of competing research programs in economics also think in methodological terms, albeit not in the professionalized language of economic methodologists and philosophers. Since history has yet to separate the winners from the losers, practitioners are not reluctant to defend their views in general methodological terms (as in the extensive debate over the merits and methods of experimentalism). An inadvertent consequence, then, of the de-emphasis of philosophy and methodology of economics in the history of economics is a general lack of interest in the recent history of economics. This, I suggest, may have two unfortunate effects on the history of economics as a field: it may make the field even more remote for economists generally; and it tends to leave historians of economics rather ignorant about the current changes in economic methods and theory. Imagine that in the not-sodistant future economists look back and wonder about how economics evolved at the end of the twentieth century. As things stand now, they 
are unlikely to receive much assistance from current historians of economics who by and large seem to be waiting until the story is fully over (though there are important exceptions).

\section{Is it fair to say that Keynes is a central figure for you? Why is that?}

Keynes was a central figure for me early in my career, seen as a philosopher-economist and as an inheritor of (a much revised) classical political economy devoted to understanding the economy as a whole. At least this was an assumption of my training in the history of economics at Michigan State University (under John P. Henderson, who wrote a comprehensive intellectual biography of David Ricardothe subject of my dissertation-and who was active for many years in the History of Economics Society).

But that I worked on Keynes (rather than Ricardo) came by way of an accident. I was assigned at the 1987 Cambridge (MA) HES conference to discuss a paper by Suzanne Helburn on Keynes's unpublished early Apostles papers, written under the influence of the philosopher G. E. Moore. I was surprised to find that I basically knew what those papers were about in virtue of my having studied Moore and the early twentieth century meta-ethics tradition in Anglo-American philosophy in my philosophy training. I also knew what the critiques were that had developed within philosophy regarding this tradition, and concluded that Keynes had lived long enough to have known what they were too. This meant to me that he had probably modified or abandoned many of his early views, including those from about the same time in his Treatise on probability (Keynes 1921)-whose underlying epistemology had also subsequently been soundly criticized by philosophersparticularly as the philosophical assumptions in his later economics were so different. Since the standing view at the time the Apostles papers emerged was that Keynes's later thinking about uncertainty flowed from the Treatise on probability, I believed the story had to be retold, which I did in my book Keynes's philosophical development (Davis 1994), basically in order to rescue Keynes's economic thinking from association with faulty philosophical positions I believed it could be shown he had rejected.

Separately from all this, I also believed that Keynes was essentially correct in his diagnosis and analysis of mixed capitalist market economies, and that the post-Keynesian research program with its particular emphasis on finance and uncertainty is superior to more 
standard contemporary macro reasoning. So my views as an economist interacted with my views as a philosopher and historian of economics.

Though my economics $\mathrm{PhD}$ and first HOPE publication were on Ricardo, following Henderson's lead and my original interest in classical political economy I was not much interested in the philosophical aspects of Ricardo's work, and so this focus died. I guess he was not enough of a philosopher-economist to sustain my interest. In an indirect way, however, my work on Ricardo got rehabilitated in a number of papers I wrote on Piero Sraffa, who reintroduced Ricardo's thinking as a rehabilitation of classical economics and a critique of neoclassical economics. In fact my experience was similar to what happened to me with Keynes. When I first worked on Sraffa's 1926 Economic Journal paper criticizing Alfred Marshalls's laws of returns analysis, I saw that the critique Sraffa was generally believed to have delivered against Ludwig Wittgenstein's early Tractatus was entirely parallel to Sraffa's critique of Marshall and neoclassical economics of about the same time (Davis 1988). So it was again clues from the history of philosophy that led my investigation and my writing in the history of economics. I subsequently wrote on a number of links between Sraffa, Keynes, and Wittgenstein (Davis 1996; 1998; 2002), assuming that their philosophical positions were what were ultimately at issue. Most recently I have a paper rethinking the Sraffa-Wittgenstein relationship based on new information from the Sraffa archive (and also from Wittgenstein's letters) about Sraffa's attachment to the anti-logical positivist physicalism view of early twentieth century philosophy of science (Davis, forthcoming).

Many commentators and critics still talk about mainstream economics in terms of a single dominant ('hegemonic') neoclassical school, but you argue that this is actually out of date, e.g., in "The turn in recent economics and return of orthodoxy" (Davis 2008).

My take on this, as I argued in the 2008 paper, comes from taking the long view on the history of economics. I think anyone who studies the history of economics must come to the conclusion that paradigms do not last forever, and new dominant paradigms are substantially different from old dominant ones. The idea that history does not really change things, or that there is some kind of eternal recurrence of mainstream theories, strikes me as being without any basis historically, though these kinds of views are popular in economics, 
including among heterodox economists (most of whom are not historians of economics). Further, if we use (sociology of scientific knowledge) reflexivity reasoning that invites us to ask what drives our own behavior, we must note that our lifetimes are short, and if through much of our careers things have not changed much (the thirty years of the first half of postwar economics), it is natural for us to infer that there is no change in economics.

Of course it is not hard to make such continuity arguments about postwar economics if one selects broad enough themes. To be fair, my own view that there is significant change in economics is also subject to criticism in terms of what I focus on. So I doubt this debate is going to be easily resolved (maybe not until more time has passed), and how it is waged will depend on how people understand the details. For example, no one denies that experimentalism is something new in economics (like econometrics was decades ago). So if things are still the same in economics today as circa 1970, one must show that the thousands of experiments that have been done over the last several decades only confirmed for the profession past theories and doctrines, and have not impacted mainstream economics in any significant way. Many economists, including mainstream economists, would dispute that. My impression, then, is that people making the argument that things are the same have not really looked at what is going on in experimentation in relation to standard theory (for example, in regard to ultimatum games and the public goods voluntary contribution game). According to Vernon Smith, who has a pretty good handle on the history of experimentation and is surely in the mainstream, standard theory, especially rational choice theory, has been largely shown not to be empirically supported (Smith 2010). Many experimentalists share his view. So how economics is changing, if it is, I think needs to be more carefully investigated.

One of the problems for heterodox economists in this regard, I should add, is that since they often emphasize their differences from mainstream theory (which is reasonable given the latter's dominance in economics), a changing mainstream makes for a moving target. This is reflected in the rise of behavioral economics: what we are to make of it for the overall development of economics is yet unclear, especially with rival behavioral views (the "old" Simon plus computation approach versus the "new" Kahneman-Tversky approach). Further, what is going on in the mainstream is very fine-grained, as for example in the 
extensive debate about the nature of motivation (post the simple selfinterest hypothesis). So this means there is a considerable research burden for heterodox economists (and historians of economics) in terms of what they need to review to form judgments about the current state of economics. But people's own research programs usually crowd this out. My guess, then, is that there are generational issues in training here. Scholars tomorrow, historians, and heterodox economists, will be simply better able to judge these questions about the state of economics because they will have grown up in the middle of these debates.

\section{Does this have implications for economic methodology?}

Very much so. The past history of economic methodology, with the critique of logical positivism, Popper, Kuhn, Lakatos, sociology of scientific knowledge, and so on, was very much a general philosophy of science approach applied to economics. Needless to say this was of little interest to practicing economists, and accordingly probably served to isolate and marginalize the field of methodology. Economic methodology now is quite different in its focus on the epistemological, ontological, and normative commitments underlying new research methods in economics (as reflected in what gets published in the Journal of Economic Methodology). So it is much closer to economic practice than it was before, but this also makes it hard to say what economic methodology is about, since there are so many threads and issues. As one example, agent-based modeling, as in Alan Kirman's (2011) work, attempts to explain markets as somehow 'self-organizing' rather than being ordered in a traditional micro-foundational way. Thus, one methodological issue is what are the epistemic credentials of the concept of self-organization as compared to those of the traditional foundations idea? There are many new questions of this sort in recent economics.

Within heterodox economics you have been particularly involved with 'social economics' (e.g., as an editor of the Review of Social Economy and president of the Association for Social Economics). What is social economics? Is it a school of heterodox economics, like Marxian or post-Keynesian economics, or something more like a movement?

Social economics is a school of heterodox economics, not only in light of the characterization of heterodox economics I give above, but also because of its rejection of the fact-value distinction embraced by 
orthodox (and some heterodox) economists. For social economists, both our thinking and the economy are irreducibly value-laden. Sometimes we can reasonably put value associations aside, but many times we do so at our peril. In addition, social economics is pluralistic with respect to values in economics. Whereas mainstream economics is explicitly welfarist (and implicitly libertarian), social economics recognizes equity, justice, fairness, dignity, human rights, responsibility, and the like-the full gamut of human normative concerns-as involved in economic life. So social economists reject the view that there is a distinct economic domain of life in which other values are not involved, and argues that the mainstream view that the economic domain is separate and distinct is just a means of promoting one system of values at the expense of others.

In addition, social economics is the economics of forms of social organization distinct from the market and state associated with the cooperative non-profit sector. This sector is in fact amazingly large and diverse, but remarkably it is little studied by economists, even hardly recognized, though it can be argued that both the market and state depend upon it in a variety of ways. In my view, the profession's overlooking of the social economy is due to a long history of ideological debate over the relative merits of market and state. This may change with new currents in recent economics, since one of the main findings of experimental and behavioral research is that people often cooperate, and do so on account of how their local interaction is organized.

One major ambition of the Association for Social Economics, then, is to convey its view that values matter in economics, and contest the fact-value distinction. Unfortunately there is not a lot of reason to be optimistic here, since the positivistic view that economics is a value-free science is very strong among economists and in society's desired view of economics and science. On the other hand, since much current behavioral and experimental research is now devoted to investigating 'pro-social' motives for behavior and coordination problems, mainstream economists may be moving toward allowing that the economy is not value-free even if they continue to believe that economics is value-free!

You have mentioned the fact-value dichotomy several times. There seem to be three distinct ways of understanding the fact-value distinction in economics, though they are much entangled in practice 
and in the rhetoric of heterodox economists: metaphysical, normative, and methodological. Firstly there is the metaphysical 'dichotomy' (which Hilary Putnam has criticized so effectively, e.g., Putnam 2002) associated with the now somewhat anachronistic philosophical position of positivism which claimed that facts and values were of quite different kinds and only empirical facts (and deductions) could count as knowledge. Secondly there is the normative proposition that economists should stick to empirical and formal analysis because the pursuit of objective truth, rather than ethical analysis, ideology, or activism, is what proper scientists do. Hence it is wrong (a failure of professional ethics) to insert one's value judgments into one's technical analysis. And thirdly there is the methodological position that values do not matter for economic life and therefore for economic analysis.

My question is what do you think of the normative interpretation of the fact-value distinction? Are there not good reasons for economists to have a professional identity as scientists rather than as ideologues, moralists, or activists? For example in allowing easier communication and debate between economists, and making their policy claims and advice to governments and the public more trustworthy.

I think there are two propositions operating in the normative interpretation you offer. First, there is the proposition that economists and scientists should not be ideologues, and should not inject their value judgments into their work. Second, there is the proposition that empirical and formal analysis are a domain of objective truth, where objectivity is a matter of being value-free. The second proposition is in my view a species of what Putnam rightfully complains about. When I argue that ordinary scientific discourse is value-laden, I reject both the idea that there is an objective domain of investigation that is fully valuefree and the idea that the value domain itself is not objective.

The claim that the value domain is subjective derives from the 1930s logical positivist doctrine regarding values, namely, emotivism. That in turn draws on Hume's old is-ought dichotomy, which many have argued is a false dichotomy in that there are many 'is' statements which smuggle in 'ought' statements (Myrdal 1953; Boumans and Davis 2010, 173ff.). For example, it appears that statements using the concept of equilibrium are value-free, but it can also well be argued that explaining the market system in terms of some natural balance idea rather than 
in terms of social conflict and power is ideological, thus value-laden. I do not say all economic ideas are significantly value-laden. But many of them, including some of the most fundamental, do imply or subscribe to various values about how we ought to see the world, even if the statements using them neither employ ought language nor point clearly to implied values.

This puts the first of the two propositions I distinguished above in a different light. I agree that economists and scientists should not be ideologues, but I interpret behaving in this way as a matter of denying and concealing the values they hold under the banner of objectivity and the Humean dichotomy. Most economists, for example, are strongly proindividual freedom. Freedom is obviously an important value, but why pretend that an economics that makes it central (often in such a way as to exclude other values such as equity and justice) is not employing that value? So objective science for me is about being clear about your values. I regard policy-makers as trustworthy when I feel they are open about their value agenda. Again, to be clear, not everything in economics turns on values, so there is much empirical and formal analysis which can be engaged in by economists who have quite different values. Generally speaking, my view of objective science is a pluralist science in which different views over what we value interact with our investigation of the way the world works in a causal sense.

You have become very interested in another heterodox school of economics that many will find surprising to be classified as economics at all: the capability approach. Firstly, could you explain why you see it as a school of economics, and second, what lies behind your particular interest in it?

I find it paradoxical that so many economists see the capability approach as outside economics. That is due, I believe, to the hegemonic dominance of welfare theory in economics with its utilitarian individual basis. But in all other regards the capability approach is very standard. It is about resources, choice, economic growth, and well-being and freedom. Its dismissal by much of the profession thus demonstrates to me the unacknowledged power of welfarism, and utilitarianism generally, as philosophical assumptions. The capability approach has an entirely different view of what a person is-a deliberating, active beingwhereas mainstream economics operates with a nineteenth century mechanical psychology view. 
Unlike many people I am fairly optimistic about the future for the capability approach. Its view of the person and human development resonates with what I believe people today generally think, that is, that people can develop their capabilities over their lifetimes. Given, however, that the economics profession is so locked in and pathdependent in its commitment to the welfarist-utilitarian view, we should not expect it to significantly embrace the capabilities approach in the near future. Assuming, then, that the capability approach continues to be employed by other social scientists concerned with human development, it seems we should expect considerable schizophrenia in economic social policy deep into the 21 st century.

As for my own interest in the capability approach, as is clear from what I say above, it derives from my interest in the theory of the individual, which I regard as the central philosophical issue in economics.

You are well known for your particular interest in what may seem an obscure issue in economic theory-personal identity. Could you explain why economists should take identity seriously?

There are two reasons for my concern with individuals and their identity, one historical and one scientific. Historically, there is no obvious reason to think, from the record of humanity, that individual people count for anything in their constant slaughter and terrible abuse over thousands of years in the name of 'higher' causes. But despite this history people around the world seem to believe individuals are important (an important expression of which is the pervasive desire for democracy). I think this is a fundamental historical discovery about human life, made over the last several centuries, that today we often take for granted but which needs much more thought. It begins with asking what an individual is, or what personal identity consists in. Unless you are offering a religious answer to this question (which I am afraid may be one underlying basis for Homo economicus in the analogy between the doctrine of the human soul and an atomistic individual), I think one finds this one of the most difficult questions to answer.

Scientifically speaking, on the other hand, what economics offers us regarding explaining the individual, despite its reputation as being the one social science that is about individuals, is not very helpful, since it assumes without scrutiny an essentially ideological view-that people are independent and untrammeled in their exercise of choice. While 
economics has generally been good at examining the exogeneityendogeneity logic of economic processes, it has nonetheless failed to investigate the degree of endogeneity (or boundedness) of individuality itself. Nor does it even have plausible grounds for supposing that individuality is exogenous. The Homo economicus preferences conception of the individual, as I emphasize in my recent (2011) book, is circular, meaning that it assumes individuality-a person is defined as a collection of their own preferences-in order to say that the person thus understood is an individual.

So if economists take a concern for individuals as a central historical value underlying their work-a normative individualism-and take that seriously, then their scientific work requires that they explain the nature and influence of individuality on the economy better than they do. For me, whether economists are able to do this will be a crucial test of the relevance of economics as a discipline in this century.

Is it true that economics is about individuals rather than individual choice? Some might say (for example, Teschl 2011, 75) that in representing individuals as unique preference orderings economists are merely constructing an abstract model for use in studying rational choice, and do not intend that model to be taken seriously as an account of what people are.

There are two problems with this view in my opinion. First, the formalist, anti-realist impulse it serves tells us that whether economics has any connection to the world is irrelevant. I do not believe people who advocate this view actually think this, so their problem seems to be that they have not thought out the whole range of issues associated with explaining how economics connects to the world. Second, if a formal model of choice can be applied to any and every candidate agent (single person, group of people, part of a person, animal, machine, and so on), why should we believe it applies to any in particular? That is, the formal model of choice is essentially indiscriminate and so is in no position to make any ontological claims.

You brought out a well-received book on how orthodox and heterodox economics conceive of the identity of economic agents in 2003. Last year you published a new book that seemed to go much further in proposing how mainstream economics should think about identity. 


\section{Could you outline how you now think about identity in economics, and what economists should do about it?}

The 2003 book, The theory of the individual in economics, contrasted the standard un-embedded Homo economicus individual with individuals seen as socially embedded to examine whether a person could be both socially embedded and individual. Traditionally, heterodox economics was about groups and not individuals, and neoclassical economics about individuals and not groups. I thought this was a false dichotomy: neoclassical economics does not succeed in showing that an atomistic being is an individual and heterodox economics actually has grounds for saying that people have a sort of individual autonomy, albeit one that depends on their relations to others.

What drove the argument were two ontological criteria of identity (individuation and reidentification through change), implied by the concept of an individual, which I used to evaluate different conceptions of the individual. Failing those criteria means that one does not have a conception of the individual that can be said to refer to real world individuals. I argued that Homo economicus fails both criteria and that most heterodox conceptions can satisfy the individuation criterion but not the reidentification criterion. The latter matter has not been adequately worked out by heterodox economists, in my view. But the 2003 book only evaluated neoclassical mainstream economics. So the 2011 book, Individuals and identity in economics, evaluates the conceptions of the individual in the new research programs in economics (behavioral, experimental, game theory, evolutionary, and so forth). It also tries to go further than the previous book to set out a capabilities conception of the individual that satisfies both criteria, and thus tells us what personal identity consists in (at least in economics). The argument of the book progressively assembles what this involves. It starts by emphasizing, through critique of behavioral economics and game theory views of the individual, how individuality depends on relations to others. It then puts this into evolutionary terms with a role for learning. Here I draw on Herbert Simon and the idea of self-organization (Simon 1955; 1956). Finally, it frames this relationalevolutionary conception in terms of capabilities (for a capabilities conception of the person); includes social identities among a person's capabilities; and then defines personal identity as a special capability one may (or may not) develop for maintaining a changing narrative one keeps of oneself with the help of others. 
Given the philosophical character of the book, my ambition for it is modest. At the very least I hope that the issue of what individuality involves becomes an issue in economics, and that economists recognize that taking individuality as exogenous is unscientific and not in keeping with their standard method of asking what happens when something previously thought exogenous is re-conceived as having determinants within one's analysis. One way I think this might begin to come about is through an examination of the social identity-personal identity connection. People's social identities change over their lifetimes, and change who they are. So choices people make in this regard reverberate back upon their future choices, showing endogeneity in individuality.

\section{I discovered in reading your CV that you have been involved in} the nominations process for the Economics Nobel Prize. That sounds tremendously exciting. Could you say something about why you were selected, what it involved, and what new insights or perspectives this gave you on the prize?

I became a nominator when I began at the University of Amsterdam in 2002. I don't know why I was selected-though I assume it had to do with the long standing European respect for the University of Amsterdam in the history of economic thought and economic methodology, going back to the original chair of Johannes Klant, and through Mary Morgan and Mark Blaug. I am not involved in later rounds of vetting individual candidates, which plays an important role in the determination of the Prize. But I was struck from the beginning by the nature of the nomination itself: one is asked to give a one sentence statement of the "discoveries, inventions, and improvements" of the nominee(s), and then add a longer statement explaining this.

As an historian of economics and methodologist, an emphasis on originality seems to me naïve for a number of reasons. In any event, for many years I nominated Mark Blaug, arguing that he had 'created' the field of economic methodology (though of course there was methodological reasoning long before Blaug), which I took to be an invention and improvement for economics par excellence. Of course this is likely not quite what the Nobel committee means by "discoveries, inventions, and improvements", and had Mark received the prize (which I genuinely believed he deserved), I and everyone else would have been astounded, given the general disrespect for history of economics 
and methodology in the profession. Nonetheless I thought the case should be made both for Mark and for the history of economics.

As well as a substantial publication record, you have served in a number of institutions (journal editorships and associations) associated with your research interests. What is your view of the health of the institutions of philosophy and economics? Do they benefit or lose from their inter-disciplinary orientation?

I think the trend in general is clear regarding interdisciplinarity in economics and science: there will be more of it. The natural sciences are significantly ahead of the social sciences in this regard, but people who think institutionally about the long term strategies for the development of knowledge and science in foundations, universities, and government fully recognize this trend and generally support it. One might say that well established disciplines tend to exhibit diminishing returns to doing the same thing, and that the real gains are from going beyond identifiable disciplines. The good news in my view on this score is that all the new research programs in economics have important origins in other sciences. So the door is more open than it has been.

As for philosophy and economics in particular, it seems that there is considerable philosophical reasoning throughout science, though it is not always framed in terms of the issues and debates in philosophy itself. So increased interdisciplinarity could raise the profile of philosophy in economics. Perhaps it might be argued that in a world in which interdisciplinarity increases, philosophical thinking gains in importance as a broadly shared conceptual apparatus. I think this is a partial explanation for the rise and professionalization of methodology and philosophy of economics in the last several decades, and so I am optimistic on this score about economics and philosophy as a distinct domain of research. We now have well established journals in the field that have created space within which research can be done. That the Erasmus Journal of Philosophy and Economics has so quickly become successful (!) seems a reflection of this.

How has your own interdisciplinary work been received by the mainstream economics profession and the economics departments in which you work? 
I have been fortunate at Marquette University where my colleagues have supported my research, though my department does mainly empirical research. It helps that I am genuinely interested in economics, represent myself as an economist, and am interested in my colleagues' empirical research and modeling intuitions as an instruction in economists' practice. I regularly tell myself I have been missing something when a colleague explains what he or she is trying to do in some piece of research. It is also worth saying that the Catholic mission of Marquette has made my type of research with its emphasis on social values and the dignity of the individual more acceptable than it might have been in a state-supported university. In fact I was hired at Marquette to replace a long-time member of the department, Peter Danner, who taught economics and ethics, as I continue to do. Finally, I am in a college of business, which means I work in an environment of different business fields, which might be argued to provide a more pluralistic environment.

For most of my time over ten years at the University of Amsterdam my research and that of my colleagues was strongly supported. (I taught three courses every second fall term, and took leave from Marquette.) Unfortunately over the last two years people in leadership positions there at the faculty of economics decided that the history and methodology of economics (HME) was not important, and in conditions of a financial emergency associated with chronic budget shortfalls closed down the HME group. That included sacking my very accomplished and, in our field, well-respected colleagues Marcel Boumans and Harro Maas, who had been associate professors there for many years, and ending the chair position in HME, which I held, which had been at the faculty for decades. We had six courses in the history and methodology of economics; engaged and enthusiastic students; a research group of up to a dozen people; a master degree in HME; PhD students; and a required methodology course for bachelor students. I do not think there was a better program in the world in our field. We also had great interaction with the London School of Economics, the history of economics people at Duke University, history of economics people in Paris, and the Erasmus Institute for Philosophy and Economics. The HME group was internationally recognized, and attracted students from across the world. Our financial footprint, in fact, was quite small compared to other groups, and by a number of measures of output per person we were more productive than many other research groups at Amsterdam. 
Since I fully believe the faculty financial emergency could have been addressed without eliminating the group, I can only put what happened down to prejudice against our field, plus the usual on-going territorial aggrandizing that has been a key factor in the elimination of history of economics from most American universities. It is interesting to me also, that with a few exceptions, members of the economics faculty at Amsterdam made no effort on the HME group's behalf to resist what happened or even personally expressed regret or concern to those who lost their jobs. I find this reprehensible.

The loss of this program was a blow to our field. There are now few places in the world training $\mathrm{PhD}$ students in history and/or methodology of economics. So in the final analysis the situation for economics and philosophy is mixed: considerable achievement with an uncertain future. Great weight, in my view, should be placed on restoring $\mathrm{PhD}$ training in the field, something that is being done, for instance, through generous grants from the Institute for New Economic Thinking at Duke University under Bruce Caldwell.

\section{REFERENCES}

Boumans, Marcel and John B. Davis. 2010. Economic methodology: understanding economics as a science. London: Palgrave Macmillan.

Davis, John B. 1988. Sraffa, Wittgenstein and neoclassical economics. Cambridge Journal of Economics, 12 (1): 2936.

Davis, John B. 1994. Keynes's philosophical development. Cambridge (UK): Cambridge University Press.

Davis, John B. 1996. Convergences in Keynes and Wittgenstein's later views. European Journal of the History of Economic Thought, 3 (3): 433-448.

Davis, John B. 1998. Sraffa and Keynes: differences and shared perspectives. Il pensiero economico italiano, 6 (1): 57-78.

Davis, John B. 2002. Gramsci, Sraffa, Wittgenstein: philosophical linkages. European Journal of the History of Economic Thought, 9 (2): 382-399.

Davis, John B. 2003. The theory of the individual in economics: identity and value. London: Routledge.

Davis, John B. 2008. The turn in recent economics and return of orthodoxy. Cambridge Journal of Economics, 32 (3): 349-366.

Davis, John B. 2011. Individuals and identity in economics. Cambridge (UK): Cambridge University Press.

Davis, John B. Forthcoming. The change in Sraffa's philosophical thinking. Cambridge Journal of Economics.

Keynes, John Maynard. 1921. A treatise on probability. London: Macmillan.

Kirman, Alan. 2011. Complex economics: individual and collective rationality. London: Routledge. 
Myrdal, Gunnar. 1953. The political element in the development of economic theory, trans. Paul Streeten. London: Routledge.

Putnam, Hilary. 2002. The collapse of the fact/value dichotomy and other essays. Cambridge (MA): Harvard University Press.

Samuels, Warren J. 2011. Erasing the invisible hand: essays on an elusive and misused concept in economics. Cambridge (UK): Cambridge University Press.

Schabas, Margaret. 1992. Breaking away: history of economics as history of science. History of Political Economy, 24 (1): 187-203.

Simon, Herbert. 1955. A behavioral model of rational choice. Quarterly Journal of Economics, 69: 99-118.

Simon, Herbert. 1956. Rational choice and the structure of the environment. Psychological Review, 63: 129-138.

Smith, Vernon. 2010. Theory and experiment: what are the questions? Journal of Economic Behavior and Organization, 73 (1): 3-15.

Sraffa, Piero. 1926. The laws of returns under competitive conditions. The Economic Journal, 36 (144): 535-550

Teschl, Miriam. 2011. Review of John B. Davis's 'Individuals and identity in economics'. The Erasmus Journal for Philosophy and Economics, 4 (2): 74-82.

http://ejpe.org/pdf/4-2-br-2.pdf

John Davis's Webpage:

http://business.marquette.edu/faculty/directory/john-davis 